\title{
Platelet rich plasma associated with heterologous fresh and thawed chondrocytes on osteochondral lesions of rabbits
}

\author{
[Associação de plasma rico em plaquetas e condrócitos heterólogos frescos e descongelados em lesão \\ osteocondral de coelhos] \\ R.R. Filgueiras ${ }^{1}$, R.J. Del Carlo $^{1}$, N.P. Alves ${ }^{2}$, M.I.V. Viloria ${ }^{1}$, C.M. McManus ${ }^{3}$, \\ M.B. Castro $^{3}$, F.P.F. Filgueiras ${ }^{3}$, B.S. Monteiro ${ }^{1}$, \\ R.M. Almeida ${ }^{3}$, R.R. Andrade ${ }^{3}$ \\ ${ }^{1}$ Universidade de Viçosa (UFV) - Viçosa, MG \\ ${ }^{2}$ Autônomo - Brasília, DF \\ ${ }^{3}$ Faculdade de Medicina Veterinária e Zootecnia - Universidade Federal de Brasília (UnB) - Brasília, DF
}

\begin{abstract}
Chondrocytes obtained from stifle joint of New Zealand White rabbits were cultivated. Half of cells were maintained in culture for later implantation and the others frozen during six months to evaluate viability. A circular osteochondral defect was created in the right stifle of other twenty seven rabbits. The control group (CG) received no treatment. The thawed (TH) and fresh $(\mathrm{FH})$ heterologous groups received, respectively, an implant of cultivated thawed or fresh heterologous chondrocytes associated with platelet rich plasma (PRP). The CG group showed greatest pain and lameness compared to the other groups seven days after the implantation. Microscopically, at 45 and 90 days, the TH and FH groups showed filling with cartilaginous tissue containing chondrocytes surrounded by a dense matrix of glycosaminoglycans. In the CG group, healing occurred with vascularized fibrous connective tissue without integration to the subchondral bone. Cryopreserved heterologous chondrocytes were viable for implantation and healing of osteochondral lesions; the association with PRP allows the fixation of cells in the lesion and offers growth factors which accelerates repair with tissue similar to articular hyaline cartilage.
\end{abstract}

Keywords: rabbits, articular cartilage, chondrocyte implantation, platelet rich plasma, type II collagen

\section{RESUMO}

Cultivaram-se condrócitos obtidos da articulação do joelho de coelhos. Metade das células foi mantida em cultura para posterior implantação, e a outra metade foi congelada durante seis meses com a finalidade de avaliar a viabilidade. Criou-se um defeito circular osteocondral no joelho direito de outros vinte e sete coelhos. $O$ grupo controle $(G C)$ não recebeu tratamento. Os grupos descongelado $(T H) e$ fresco $(F H)$ receberam, respectivamente, implantes heterólogos de condrócitos cultivados descongelados e frescos, associados com PRP. O grupo GC apresentou maior dor e claudicação em comparação com os outros grupos aos sete dias após o implante. Microscopicamente, aos 45 e 90 dias, os grupos TH e FH mostraram preenchimento da falha com tecido cartilaginoso contendo condrócitos circundados por uma matriz densa de glicosaminoglicanos. Nesse período, no grupo CG, a cura ocorreu com tecido conjuntivo fibroso vascularizado e sem integração com o osso subcondral. Condrócitos heterólogos criopreservados foram viáveis para implantação e tratamento de lesões osteocondrais; a associação com o PRP permitiu a fixação de células na lesão e ofereceu fatores de crescimento que aceleraram a reparação com o tecido semelhante à cartilagem hialina articular.

Palavras-chave: coelho, cartilagem articular, colágeno tipo II, implante de condrócitos, plasma rico em plaquetas

Recebido de 25 de junho de 2012

Aceito em 17 de julho de 2013

E-mail: richardfilgueiras@gmail.com 


\section{INTRODUCTION}

The matrix of hyaline articular cartilage shows low number of cells and a high concentration of water which connects to the proteoglycan molecules synthesized by chondrocytes. Together with type II collagen, the hyaline matrix maintains a tissue rigidity and elasticity (Grodzinsky et al., 2000). For repair of superficial lesions, chondrocytes close to the injury multiply and synthesize a new matrix, filling the void with tissue similar to hyaline cartilage. Nevertheless, a week after the injury, this response ceases and marginal chondrocytes enter in apoptosis and newly formed tissue frees itself from health tissue (Trippel and Mankin, 1994; Fossum, 2007).

A bruise forms over the lesions which reach the subchondral bone, releasing several leukocytes, mesenchymal cells and plasma rich in chondrogenic factors such as platelet derived growth factor (PDGF) and insulin-like growth factor (IGF) (Schmidt et al., 2006). This is followed by modeling of the fibrin cloth, constituting a framework for the fibroblasts which begin to occupy the injured area. About 15 days after the lesion, the fibrous tissue suffers hyalinization due to differentiation of mesenchymal cells in chondroblasts showing a fibrocartilaginous aspect (Souza et al., 2000).

An alternative to promote the articular cartilage regeneration is prolonging the permanence of an elevated number of active chondrocytes in the area of the injury. Cultivated chondrocytes can be implanted at high concentrations, remaining active for a prolonged period until the new matrix integrates into the subcondral bone (Jones and Peterson, 2006). Preliminary results of heterologous cultures demonstrated the absence of inflammation or rejection in periods varying from three to eight months (Stevenson, 1987; Hidaka et al., 2003).

The fixation of cells in the injured site during articular movement influences the quality of results. A Periosteal graft sutured over the lesion is the elective technique in humans and horses (Schneider et al., 2004; Jones and Peterson, 2006). Platelet rich plasma (PRP), an adherent substrate, is used in small animals such a fixation agent, offering chondrogenic growth factors (Schmidt et al., 2006; Drengk et al., 2008).
We describe clinical and morphological aspects post-implantation of fresh and thawed heterologous chondrocytes associated with platelet rich plasma in osteochondral lesions experimentally produced in rabbits stifles.

\section{MATERIAL AND METHODS}

This experiment was submitted to analysis and approved by the Animal Use Ethics Committee of Federal University of Vicosa, Brazil (Protocol \# 076/2005).

The cartilage was obtained from biopsy of the left stifle joint of a male New Zealand White rabbit, one year old, after anesthesia with propofol (Propofol; Cristália Chemical Products, Brazil) $(10 \%, 10 \mathrm{mg} / \mathrm{kg}$ IV), followed by an epidural anesthesia with ropivacaine (Ropivacaina; Cristália Chemical Products, Brazil) $(0.75 \%, 2.25 \mathrm{mg} / \mathrm{kg})$. Cartilage fragments were removed from the femoral condyles, placed in a sterile metallic tray and cut in pieces with approximately $1 \mathrm{~mm}^{2}$ of size. Eight of these fragments, free from soft tissue and subchondral bone, were selected. The articular capsule, subcutaneous tissue and skin were sutured and the rabbit received cephazolin (Cephazoline; Bristol Myers Squibb, USA) 10\% (30mg/kg IM), and ketoprofen (Ketofen, Merial Animal Health, USA) $10 \%(2.0 \mathrm{mg} / \mathrm{kg} \mathrm{SC})$, every 24 hours, during three days.

The technique used for cell culture was adapted from Filgueiras et al. (2011). Cartilage fragments were deposited in sterile plastic tube containing $10 \mathrm{~mL}$ of Ham's F12 culture medium (Ham's F12, Gibco-Invitrogen, USA) with addition of a $1 \%$ antibiotic-antimycotic solution (Penicillin G, streptomycin and anfotericin B; GibcoInvitrogen, USA) that was maintained under refrigeration until use.

The cartilage samples were transferred to one sterile becker and submitted to enzymatic digestion during 25 minutes, in a $0.05 \%$ trypsin (Porcine trypsin; Gibco-Invitrogen, USA) diluted in $10 \mathrm{~mL}$ Ham's F12. After trypsin removal, another digestion was carried out for 30 minutes, with collagenase type I (Collagenase type I; Gibco-Invitrogen, USA) at $0.3 \%$ diluted in $10 \mathrm{~mL}$ Ham's F12. All procedures were carried out in a magnetic agitator, at room temperature and sterile conditions. 
The collagenase solution was removed, and the fragments transferred to $25 \mathrm{~cm}^{2}$ culture flasks containing $0.06 \%$ collagenase diluted in $10 \mathrm{~mL}$ Ham's F12 with $10 \%$ fetal bovine serum (Fetal Bovine Serum, Cultilab, Brazil) (FBS). The material was placed in an incubator at $37^{\circ} \mathrm{C}$, with $5 \% \mathrm{CO}_{2}$, during 15 hours. The suspension was transferred to a $50 \mathrm{~mL}$ centrifuge tube and agitated in a vortex, for a few seconds. After that, the material was filtered in a $70 \mu \mathrm{m}$ nylon filter (BD-Falcon, USA), and the suspended chondrocytes counted in a hemocytometer. Following counting, the chondrocytes were transferred to $25 \mathrm{~cm}^{2}$ culture flasks containing $5 \mathrm{~mL}$ of complete growth medium with DMEM (Dulbeco Modified Eagle Medium; GibcoInvitrogen, USA)/Ham's F12 (1:1, v/v) and 1\% antibiotic-antimycotic, supplemented with $10 \%$ FBS.

The flasks were incubated at $37^{\circ} \mathrm{C}$, at $5 \% \mathrm{CO}_{2}$, until $75 \%$ confluence was reached. After that, the chondrocytes were removed from the flask with PBS (phosphate buffered salt, $\mathrm{pH}$ 7.4) containing $0.1 \%$ trypsin and $0.02 \%$ EDTA, and washed for five minutes in DMEM medium containing $10 \%$ FBS to neutralize the trypsin. The chondrocytes were centrifuged at $400 \mathrm{~g}$ for ten minutes in a refrigerated centrifuge and underwent a new subculture. After ten subcultures, the chondrocytes were resuspended, counted in a hemocytometer and half of the cellular suspension $(2.5 \mathrm{~mL})$ distributed in nine $25 \mathrm{~cm}^{2}$ flasks to be cultivated during three days. After cellular expansion, the chondrocytes were then removed from the flasks by the trypsinization technique described before, and the pellets formed after centrifugation resuspended in $5 \mathrm{~mL}$ DMEM at a concentration of $2.0 \times 10^{6}$ cells $/ \mathrm{mL}$, distributed equally in nine centrifuge tubes that were reserved in a refrigerated recipient for later association with PRP.

The other half of the suspension was centrifuged at $400 \mathrm{~g}$ for ten minutes and resuspended in a centrifuge tube containing a cooled medium composed of DMEM and $10 \%$ FBS. To this suspension 5\% of DMSO (Dimesol; Marcolab Pharmaceutical Products, Brazil) was slowly added. This was then transferred to cryo-tubes at a cellular concentration of $2.4 \times 10^{6}$ cells $/ \mathrm{mL}$. The cryo-tubes were left in a freezer at $-20^{\circ} \mathrm{C}$ for 45 minutes and stocked in liquid nitrogen for six months.
After six months, the cryo-tubes were taken from the liquid nitrogen and quickly placed in a water bath at $37^{\circ} \mathrm{C}$ to thaw the cellular suspension. Afterwards, the chondrocytes were resuspended in complete growth medium, as described above, counted in a hemocytometer followed by cell viability determination. The chondrocytes were equally distributed in nine $75 \mathrm{~cm}^{2}$ flasks incubated at $37^{\circ} \mathrm{C}$, with $5 \% \mathrm{CO}_{2}$ for eleven days.

After cellular expansion, the chondrocytes were removed from the flasks and the pellets resuspended in $5 \mathrm{~mL}$ DMEM at a concentration of $2.0 \times 10^{6}$ cells $/ \mathrm{mL}$, equally distributed in nine centrifuge tubes which were reserved in a refrigerated recipient for later association with PRP.

Three hours before the operation, $4.5 \mathrm{~mL}$ of blood was collected from each rabbit using intracardiac puncture. The blood was transferred to centrifuge tubes containing $0.5 \mathrm{~mL}$ sodium citrate, identified and sent to the laboratory for processing. The tube content was homogenized and centrifuged at $400 \mathrm{~g}$ for 12 minutes. After centrifugation the plasma was separated from the red blood cells, placed in another sterile tube and centrifuged at $800 \mathrm{~g}$ for 15 minutes. A precipitate of platelets formed in the bottom of the tube was separated from the supernatant plasma. In this tube, $250 \mu \mathrm{L}$ of supernatant plasma and the platelet precipitate formed the PRP.

Fresh and frozen chondrocyte solutions were centrifuged at $400 \mathrm{~g}$ for ten minutes and the cellular pellet was ressuspended with the PRP of each rabbit and sent to the surgical center in a refrigerated recipient for implantation.

At implantation, the PRP with chondrocytes was associated with $125 \mu \mathrm{L}$ of coagulating solution composed of recombinant rabbit thromboplastin and calcium chlorate (HemosIL; Instrumentation Laboratories, USA). After five minutes, the formed gel was placed over the surgical lesion depending on the treatment group.

Twenty seven one year old New Zealand White rabbits (13 males and 14 females) weighing $4.0 \mathrm{~kg}$ were randomly distributed in three treatments.

The articulation of the right stifle joint of each animal was exposed and a circular osteochondral 
defect $(3.0 \mathrm{~mm}$ diameter $\mathrm{x} 3.0 \mathrm{~mm}$ depth) was produced in the trochlear groove. In animals from the $\mathrm{CG}$ group (control group) the lesion was not filled. In the Group TH (thawed heterologous) the lesion was filled with a gel containing PRP associated with thawed chondrocytes and in the FH group (fresh heterologous) with a PRP gel associated with fresh chondrocytes.

The articular capsule, subcutaneous tissue and the skin were sutured routinely and the rabbits received cephazoline $(10 \%, 30 \mathrm{mg} / \mathrm{kg} \mathrm{IM})$ and ketoprofen $10 \%(2.0 \mathrm{mg} / \mathrm{kg} \mathrm{SC})$, every 24 hours during three days.

The degree of lameness and pain was evaluated by two different evaluators and was carried out using a scale: 0 (continuous weight bearing), 1 (intermittent weight bearing), 2 (toe touches, non-weight bearing), and 3 (non-weight bearing). Pain intensity was determined after patellar palpation as follows: 0 (none), 1 (mild pain, occasional vocalization), 2 (moderate pain, frequent vocalization), and 3 (severe pain, vociferous vocalization, withdraws limb, bites, struggles).

Three animals from each group were euthanized using an overdose of sodium thiopental (Tiopental; Cristália Chemical Products, Brazil) at 15,45 , and 90 days post-operation. At necropsy, the aspect of tissue deposited in the bone lesion and the presence of adherence to the articular capsule to the lesion were evaluated. Osteochondral fragments (approximately $1 \mathrm{~cm}^{2}$ ) involving the operated area were fixed in paraformaldehyde at $\mathrm{pH} 7.4$, for 12 hours, at $4^{\circ} \mathrm{C}$. These were then decalcified in EDTA $10 \%$, $\mathrm{pH} 7.4$, at $4^{\circ} \mathrm{C}$ for 14 days. The fragments were dehydrated in alcohol and set in ultrapure paraffin. Histological cuts $5 \mu \mathrm{m}$ thick were labeled with Hematoxiline-Eosine (H\&E) and examined under an optical microscope for morphological repair tissue analysis, using Safranina $O$ to evaluate the intensity of marking of glycosaminoglycans in the cartilaginous matrix.

The presence of inflammatory infiltration was quantified using the following scale: 0 (lack of inflammation), 1 (discrete), 2 (moderate), and 3 (elevated quantity of inflammatory infiltrates).
To observe the presence of type II collagen, one osteochondral fragment was randomly selected 90 days post-operatory in each group. The specimens were cut $5 \mu \mathrm{m}$ thick and adhered to a silanized slide (Silane; Sigma Aldrich, USA). After removing the paraffin with xylol, antigenic recuperation was carried out with trypsin $1 \%$, at $37^{\circ} \mathrm{C}$ for 25 minutes. Blockage of specific proteins was carried out using goat serum at $1: 10$, for five minutes and then the specimens were incubated for 12 hours at $4^{\circ} \mathrm{C}$, with the primary antibody (mouse monoclonal antibody for type II collagen - Lab-Vision Laboratories, USA) in 1:100 dilution. The specimens were incubated with the biotinylated secondary anti IgG multispecies antibody (EasyPath; Signet Laboratories, USA), for 20 minutes at room temperature, and then marked with ultra streptavidin peroxidase (EasyPath; Signet Laboratories, USA) for 20 minutes at room temperature. After marking, the specimens were incubated with diaminobenzidine (DAB Chromogen System; Signet Laboratories, USA) for five minutes and staining with Hematoxiline 1:10 until mounting in balsam with a slide cover.

Statistical analysis was carried out to evaluate the effect of time after operation on lameness degree, pain intensity, and presence of inflammatory infiltrate. The groups were analyzed separately and the results compared using $\mathrm{F}$ test for variance analysis. The data were analyzed using SAS $^{\circledR}$ (Enterprise Guide v.4) at $5 \%$ significance level. For non-parametric analyses was used Chernoff-Savage test.

\section{RESULTS}

The digestion technique used to liberate the chondrocytes from the matrix, an enzymatic association with trypsin and collagenase, ensured the liberation of $6.5 \times 10^{5}$ cells $/ \mathrm{mL}$, with a viability of $98.5 \%$, which produced a confluent cellular monolayer after three days of culture. Low viability (16.67\%) was observed after thawing the chondrocytes. Nevertheless, after 11 days of culture, these cells multiplied and showed a viability of $98.7 \%$, when they were removed from the flasks and prepared for implantation.

The surgical method used allowed the confection of an osteochondral lesion with smooth margins and no injury to the adjacent tissue. The depth of 
the lesion, $3.0 \mathrm{~mm}$, was sufficient to place the PRP gel, which in all groups was shown to be easily manipulated with a discrete degree of adherence to the lesion immediately after application.

The TH and FH groups received a total number of $2 \times 10^{6}$ chondrocytes mixed with PRP, which after gelatinization, maintained the cells in a disperse form. Nevertheless, at application, the gel lost a great quantity of plasma and formed an agglomerated, rich in platelets and chondrocytes, adhering to the lesion.

At seven days post-operation, greater pain was felt by $\mathrm{CG}(\mathrm{p}<0.05)$ compared to the other groups. No significant difference for pain was found between the two treated groups seven days after operating, although the group $\mathrm{TH}$ showed better results with $33.3 \%$ of the animals not showing pain. A reduction in pain was seen in all groups at 15 days post-operation.

The animals from group CG showed a higher degree of lameness $(\mathrm{p}<0.001)$ in comparison with the other groups. The groups receiving treatment showed an improved degree of lameness 15 days post-operation, while $67 \%$ of the animals from group CG showed a high degree of lameness.

Gross findings after 15 days showed adherence of the articular capsule to the lesion and lack of filling tissue in the CG group animals. In animals from group FH, the articular surface was shiny, without capsule adherence, with borders of the lesion showing the beginning of a filling process with a smooth and white tissue. In TH group, filling was similar to $\mathrm{FH}$ group, with repair showing filling at the borders and in the center of the defect (Fig. 1 A, B, and C).

After 45 days, two animals from group CG showed the beginning of repair process at the lesion borders with a slightly irregular white tissue. A third rabbit showed adherence of the capsule to the lesion filled with reddish tissue with irregular surface and rough granules. In TH and $\mathrm{FH}$ groups no articular modifications were seen. The filling process was smooth and brilliant with white tissue, which extended to the center of the lesion.
After 90 days, full articular repair similar to that found after 45 days was seen in groups $\mathrm{TH}$ and FH. In the non-treated animals (CG), the synovial membrane adhered to the damaged area, determining a repair process with tissue of reddish fibrous aspect. Nevertheless, when animals were treated with PRP associated with fresh or frozen chondrocytes, repair was faster and diffuse, with tissue similar in aspect and color to hyaline cartilage without adherence of the capsule to the lesion (Figure 1 D, E, and F).

At microscopic analysis, animals from group CG showed, after 15 days, points of cartilaginous tissue in the periphery of the lesion containing extracellular basophilic matrix and chondrocytes laid out randomly at low intensity after marking with Safranine O. In the center of the repair area a granulation tissue constituted of fibers, blood vessels, and connective cells was observed. At the periphery, osteoclastic resorption of subchondral bone tissue was seen, which was necrotized. In areas where resorption occurred, a separation line formed between the repair tissue and the subchondral bone. In groups TH and FH the formation of cartilaginous tissue was seen at the borders of the lesions and in the center in group TH. The cartilage contained chondrocytes laid out in a columnar form involved in an extracellular matrix strongly marked by Safranine O. In these animals no separation line was visualized between the deposited tissue and the subchondral bone. Chondrocytes were observed in the calcification zone forming a tide line. Animals from Groups TH and FH showed significant polymorphonuclear inflammatory infiltration in the subchondral bone $(p<0.05)$ (Figure 2).

Group CG showed, after 45 days, diffuse filling with vascularized fibrous connective tissue containing collagen fibers without definite orientation. In these animals, adipose tissue was deposited from subchondral bone and there was a separation line between adjacent bone and repair tissue. Hypertrophic cartilaginous tissue was deposited in groups $\mathrm{TH}$ and $\mathrm{FH}$ with chondrocytes organized in columnar form and distributed in a matrix that was strongly stained by Safranine O. In these groups, no separation line was observed between forming tissue and subchondral bone. Below it a mononuclear inflammatory infiltrate was seen. 
In group CG, after 90 days, the microscopic findings were the same as at 45 days. Groups TH and $\mathrm{FH}$ showed filling with cartilaginous tissue containing chondrocytes organized in columnar form, forming isogenic groups and surrounded by a dense matrix strongly marked by Safranine O. In this period there was a reduction in the inflammatory process.
Only samples from groups $\mathrm{TH}$ and $\mathrm{FH}$ were marked by ultra streptavidin peroxidase, showing the presence of a matrix rich in type II collagen deposited around the chondrocytes. The specimen from group $\mathrm{CG}$ showed filling with tissue not marked by ultra streptavidin peroxidase, indicating a lack of type II collagen (Figure 3).
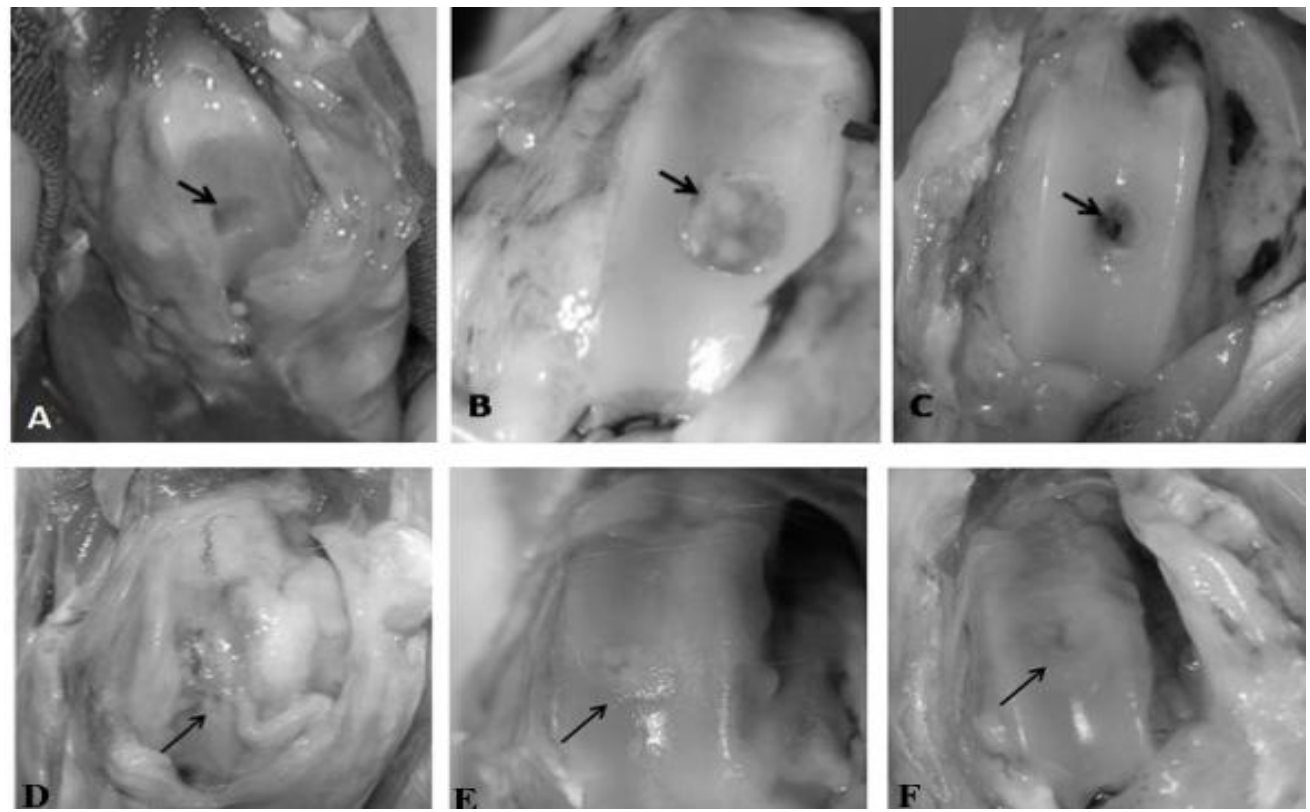

Figure 1. Macroscopic aspect of osteochondral defects in rabbits stifle at different times. 15 days postoperation: (A) Group CG: Lack of filling tissue in the interior of the lesion (arrow); (B) Group TH: Presence of tissue of hyaline aspect on borders and center of lesion (arrow); (C) Group FH: Total filling of borders and partial of center with tissue of hyaline aspect (arrow). 90 days post-operation: (D) Group CG: Filling with fibrous connective tissue and adherence of articular capsule (arrow); (E and F) Lesion totally repaired with tissue of hyaline aspect, groups $\mathrm{TH}$ and $\mathrm{FH}$, respectively (arrow).

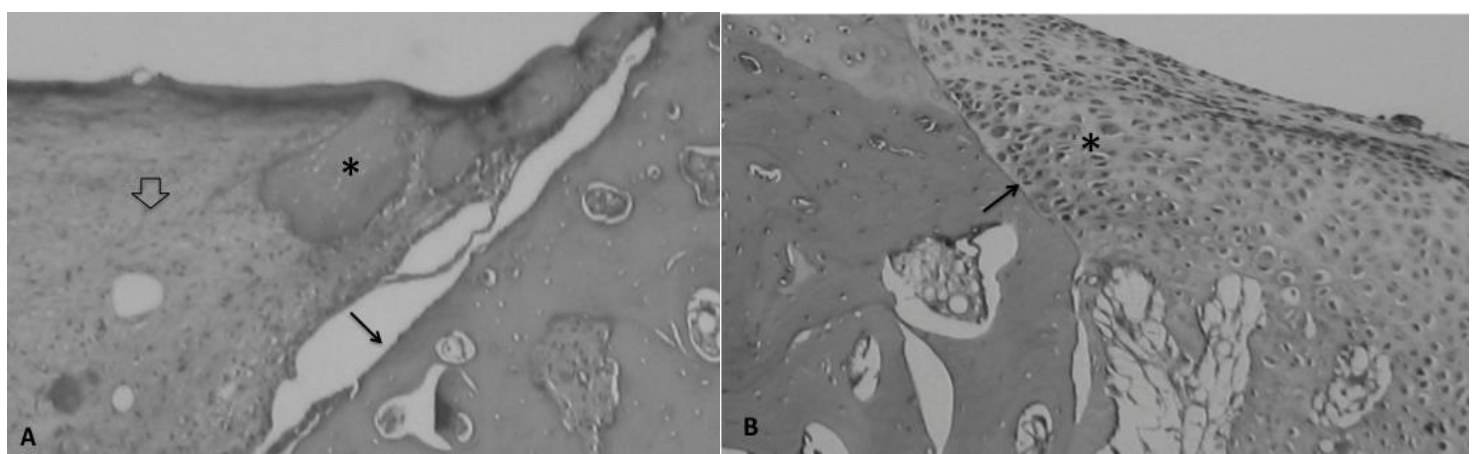

Figure 2. Histological findings 15 days post-operation (H\&E 200x). (A) Group CG: points of cartilaginous tissue in the periphery of the lesion containing extracellular basophilic matrix (asterisk), separation line formed between the repair tissue and the subchondral bone (arrow) and granulation tissue constituted of fibers, blood vessels, and connective cells (arrow head); (B) Group TH: Chondrocytes observed in the calcification zone forming a tide line (arrow) and cartilage contained chondrocytes laid out in a columnar form involved in an extracellular matrix (asterisk). 

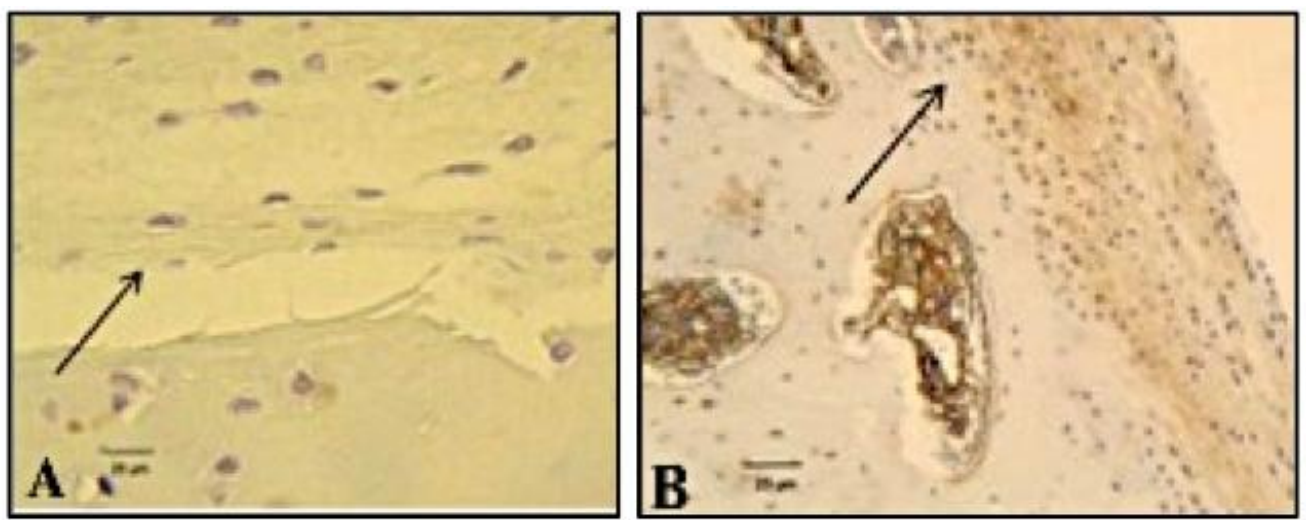

Figure 3. Immunohistochemical evaluation after 90 days post-operation, stained with ultra streptavidin peroxidase on the repair tissue deposited in the defects produced in the stifles of rabbits. (A) Group CG: Diffuse deposition of tissue loosened from the subchondral bone and without staining of type II collagen (arrow) (400 X). (B) Group TH (100X): Presence of cartilage contiguous with the subchondral bone and chondrocytes involved in a labeled brown matrix rich in type II collagen (arrow).

\section{DISCUSSION}

Cryopreservation of articular chondrocytes has been used to study in vitro repair of articular cartilage (Tavakol et al., 1993; Ishaug-Rilley et al., 1999). Recent studies showing that the implantation of heterologous chondrocytes stored in liquid nitrogen may show repair capacity similar to that of autologous chondrocytes. The present work studied the implantation of heterologous fresh and thawed articular chondrocytes. The results did not showed significant differences in the type of tissue deposited in the repair area.

Despite low cell viability observed after thawing, cryopreservation allowed for storage of chondrocytes for up to six months with little functional alterations, similar to that found by Almqvist et al. (2001) who froze chondrocytes in a culture medium containing DMSO at the same concentration used here.

There was a need to associate the chondrocytes with techniques that fixed the cells to the injured area until adsorption of these by the host site occurred. The use of a periosteal flap sutured over the lesion is difficult to carry out in small animals. Furthermore, the periostal flap presents mesenquimal cells, which migrate to the lesion and may induce the formation of fibrocartilage (Kajitani et al., 2004; Schneider et al., 2004; Jones and Peterson, 2006).
Macroscopic results show that PRP remained fixed to the lesion and, when used in association with fresh or frozen chondrocytes, aided in the reparation process with tissue similar to hyaline cartilage, allowing for a rapid clinical recovery of animals in comparison to the control group.

On the other hand, the PRP was effective as an alternative to fix chondrocytes to the lesion. It is rich in growth factors (Akeda et al., 2006), stimulating the implanted chondrocytes, and promoting proliferation via membrane receptors localized in the surface of these cells (Barbosa $e t$ al., 2008).

Kajitani et al. (2004) implanted fresh heterologous chondrocytes in cartilage lesions produced in the stifle of rabbits, observing the absence of inflammatory reaction or rejection six months later. In the present study, inflammatory infiltrates with polymorphonuclears were found after 15 days, and mononuclears after 45 days in the treated groups (Groups $\mathrm{TH}$ and $\mathrm{FH}$ ). Nevertheless, the presence of these inflammatory cells does not seem to be related to a heterologous chondrocyte rejection process.

The intense inflammatory response observed may be justified by the action of cytokines present in PRP, that can attract mononucleated fagocyte cells to the region (Barbosa et al., 2008). This is supported by the reduction in inflammation after 90 days. During this time, PRP was no longer present and therefore the chemical-tactic stimulus had ceased. 
Immunohistochemistry showed the presence of tissue similar to hyaline articular cartilage in the lesion from treated groups. This test showed the deposition of cartilaginous tissue with matrix rich in type II collagen, which in accordance with Grigolo et al. (2005), represents the final phase in the repair process in lesions treated with an implant of cultivated chondrocytes.

Adherence to the articular capsule, found in animals from $\mathrm{CG}$ group was also observed by Souza et al. (2000), and is related to the projection of the articular capsule over the lesion with the finality of recovering the surface, allowing mesenquimal cells to invade the tissue promoting repair.

A similar process was observed by Kajitani et al. (2004), who demonstrated mesenquimal cells differentiating into fibroblasts, forming a vascularized fibrous connective tissue, which filled the osteochondral lesion in animals from CG group. As well as capsular adherence, it was seen that this tissue did not integrate with the subchondral bone. These situations determined a higher degree of pain due to the stimulus of neurological receptors found in the fibrosed articular capsule and the subchondral bone exposed (Todhunter \& Johnston, 2003). Contrary to this, the animals from treated groups did not developed adherences, showing repair occurrence with tissue similar to hyaline cartilage verified by macro and microscopical analysis. The cartilaginous tissue formed in these animals was integrated with the subchondral bone, which may signify better biomechanical results.

\section{CONCLUSIONS}

In conclusion, according experimental conditions demonstrated, heterologous cryopreserved chondrocytes are viable for implantation and repair of osteochondral lesions. The association with PRP allows the fixation of cells in the lesion and offers growth factors, which accelerates the repair with tissue similar to articular hyaline cartilage. Clinically the implantation of chondrocytes associated with PRP reduces articular pain and lameness, inhibiting capsular adherence to the lesions, and allowing the integration of cartilaginous repair tissue to the subchondral bone.

\section{ACKNOWLEDGMENTS}

The present study was supported by Tecnogene Laboratory and $\mathrm{CNPq}$ (Brazilian Council of Research and Development). The authors wish to thank Dr. Elisiane Pereira from Tecnogene Laboratory and Dr Rafael Andrade from Laboratory of Experimental Surgery of UnB for installation availability.

\section{REFERENCES}

AKEDA, K.; OKUMA, M.; ATTAWIA, M. et al. Platelet-rich plasma stimulates porcine articular chondrocyte proliferation and matrix biosynthesis. Osteoarthritis Cart., v.14, p.12721280, 2006.

ALMQVIST, K.F.; WANG, L.; BRODDLEZ, C. et al. Biological freezing of human articular chondrocytes. Osteoarthritis Cart., v.9, p.341350, 2001.

BARBOSA, A.L.T.; DEL CARLO, R.J.; GOMES, H.C. et al. Platelet-rich plasma for canine bone restauoration. Cienc. Rural, v.38, p.1335-1340, 2008.

DRENGK, A.; ZAPF, A.; STURMER, E.K. et al. Influence of platelet-rich plasma on chondrogenic differentiation and proliferation of chondrocytes and mesenchymal stem cells. Cells Tisssues Organs, p.1-10, 2008. Available: $\rightarrow$ <http://content.karger.com/ProdukteDB/produkte .asp?Doi=151290>. Accessed in: 03 mai. 2012.

FILGUEIRAS, R.R.; DEL CARLO, R.J.; ALVES, N.P. et al. Effect of freezing on rabbit cultured chondrocytes. Arq. Bras. Med. Vet. Zootec., v.63, p.46-55, 2011.

FOSSUM, T.W. (Ed). Small animal surgery. St. Louis: Mosby, 2007. 1532p.

GRIGOLO, B.; ROSETI, L.; FRANCESCHI, L. et al. Molecular and imuno-histological characterization of human cartilage two years following autologous cell transplantation. $J$. Bone Joint. Surg., v.87-A, p.46-57, 2005.

GRODZINSKY, A.J.; LEVENSTON, M.E.; JIM, M. et al. Cartilage tissue remodeling in response to mechanical forces. Annu. Rev. of Biomed. Eng., v.2, p.691-713, 2000. 
HIDAKA, C.; GOODRICH, L.R.; CHEN, C.T. et al. Acceleration of cartilage repair by genetically modified chondrocytes over expressing bone morphogenetic protein-7. J. Orthop. Res., v.21, p.573-583, 2003.

ISHAUG-RILLEY, S.; OKUN, L.E.; PRADO, G. et al. Human articular chondrocyte adhesion and proliferation on synthetic biodegradable polymer film. Biomaterials, v.20, p.2245-2256, 1999.

JONES, D.; PETERSON, L. Autologous chondrocyte implantation. J. Bone Joint. Surg., v.88-A, p.2501-2520, 2006.

KAJITANI, K.; OCHI, M.; UCHIO, Y. et al. Role of the periosteal flap in chondrocyte transplantation: an experimental study in rabbits. Tissue Eng., v.10, p.331-342, 2004.

SCHMIDT, M.B.; CHEN, E.H.; LYNCH, S.E. A review of the effects of insulin-like growth factor and platelet derived growth factor on in vivo cartilage healing and repair. Osteoarthritis and Cart., v.14, p.403-412, 2006.

SCHNEIDER, L.; LEJEUNE, J.P.; DEBY, C. et al. Viability of equine articular chondrocytes in alginate beads exposed to different oxygen tensions. Vet. J., v.168, p.167-173, 2004.
SOUZA, T.D.; DEL CARLO, R.J.; VILORIA, M.I.V. Histologic evaluation of the repair process in the articular surface of rabbits. Cienc. Rural, v.30, p.439-444, 2000.

STEVENSON, S. The immune response to osteochondral allografts in dogs. J. Bone Joint. Surg., v.69, p.573-582, 1987.

TAVAKOL, K.; MILLER, R.G.; BAZETTJONES, D.P. et al. Ultrastructural changes of articular cartilage chondrocytes associated with freeze-thawing. J. Orthop. Res., v.11, p.1-9, 1993.

TODHUNTER, R.J.; JOHNSTON, S.A. Osteoarthritis. In: SLATTER, D. (Ed). Textbook of small animal surgery. Philadelphia: Saunders, 2003. p.2208-2245.

TRIPPEL, S.B.; MANKIN, H.J. Articular cartilage injury and repair. In: SILISKY, J.M. (Ed). Traumatic disorders of the knee. New York: Springer Verlag, 1994. p.19-36. 